DOI: $10.21608 / z v j z .2018 .7625$.

\title{
Effect of Different Culture Conditions on In vitro Development and Quality of Buffalo
} Embryos

Fatma A. Ibrahim ${ }^{1 *}$, Hassan H. Mansour ${ }^{1}$, Faten M. Labib ${ }^{1}$, Hussein A. Amer ${ }^{1}$ and Magdy R. Badr $^{2}$

${ }^{1}$ Theriogenology Department, Faculty of Veterinary Medicine, Zagazig University, 44511, Egypt

${ }^{2}$ Artificial Insemination and Embryo Transfer Department, Animal Reproduction Research Institute (ARRI), Giza, Egypt

Article History: Received: 7/2/2018 Received in revised form: 23/2/2018 Accepted: 27/2/2018

\begin{abstract}
This work was carried out to evaluate the quality and the developmental competence of the in vitro buffalo embryos produced under different culture conditions. Oocytes were matured in TCM 199 for $24 \mathrm{~h}$ at $38.5^{\circ} \mathrm{C}$ and $5 \% \mathrm{CO}_{2}$. After maturation, oocytes were in vitro fertilized by frozen thawed sperms capacitated in vitro by caffeine at final concentration 2 million sperm $/ \mathrm{ml}$. The sperm-oocytes were incubated in TALP medium for $24 \mathrm{hrs}$. Fertilized oocytes were cultured in Cell free media (CR1aa) or with cumulus or oviductal cell monolayers (Experiment 1), CR1aa with addition of $\left(10,20,50\right.$ and $100 \mu \mathrm{g} / \mathrm{mL}$ ) lactoferrin (Experiment 2) inside $\mathrm{CO}_{2}$ incubator with $5 \% \mathrm{CO}_{2}$ at $38^{\circ} \mathrm{C}$. The cleavage, morula, blastocyst rates were recorded and embryo cell number and mitochondrial function were evaluated. Addition of bovine oviductal cell monolayer (BOCM) to culture media significantly increased the morula and the blastocyst compared with cell free media and media with cumulus cell monolayer and also significantly increased the cell number and the mitochondrial function of in vitro produced buffalo embryos. Addition of lactoferrin by concentration $50 \mu \mathrm{g} / \mathrm{ml}$ to culture media resulted in a significant increase in rates of cleavage; morula and blastocyst compared with control or other concentrations and also resulted in an increase in the cell number and the mitochondrial function of in vitro produced buffalo embryos. It could be concluded that, addition of oviductal cells (monolayer) or lactoferrin to culture medium significantly improved the quality of in vitro produced buffalo embryos.
\end{abstract}

Key words: In vitro Fertilization, Buffalo Embryos, BOCM, Lactoferrin, Quality.

\section{Introduction}

Buffaloes represent a vital part of the agricultural economy in Egypt. However, they have low fertility rate which may be attributed to low follicular number in the ovary, low response to superovulation and high number of atretic follicles. Recently, efforts are established to enhance the reproductive efficiency of these animals using reproductive biotechnology such as in vitro fertilization (IVF) technology and embryo transfer (ET) [1].

Reproductive biotechnologies such as in vitro embryo production (IVEP) and ET may enhance genetic improvement and are needed as a tool to obtain large number of offspring from superior animals. Therefore, it has been expected that there is a positive relationship between the use of these technologies and production [2]. The culture system and the composition of the medium influence embryo quality [3]. Some studies demonstrated that the quality of the oocyte is the most important factor that influences the blastocyst rate and that the in vitro culture medium is the most important determinant of the quality of blastocyst [4]. Several authors favored coculture of embryos with cumulus, oviductal epithelial cells or with cell lines such as Buffalo rat liver (BRL). It was demonstrated that cellular co culture produces specific embryo trophic factors which improve the in vitro embryo development [1]. Lactoferrin (LF) maintains iron levels in the cell and has antimicrobial, enzymatic and antioxidant (decrease oxidative stress and apoptosis of the cells) activities [5].

Embryo quality is one of the most critical factors, which determine the output of embryo transfer. Its significance is attributed to the essential relationship between embryo quality and its developmental stage [6]. Thus, this work aimed to study the effect of different 
culture conditions on the developmental ability and quality of buffalo embryos.

\section{Materials and Methods}

\section{Ethical approve}

All procedures used in the present study were approved by the Committee of Animal Welfare and Research Ethics, Faculty of Veterinary Medicine, Zagazig University, Egypt.

\section{Oocytes recovery}

Ovaries were collected within few minutes after slaughtering of Egyptian buffalo with good health status from Bahteem slaughter house. They were put in a well-sealed container containing physiological saline and traces of Streptomycin and Penicillin at a temperature of $30^{\circ} \mathrm{C}$. Healthy oviducts also were dissected from the mesosalpinix.

Transportation of the ovaries and oviducts to the laboratory occurred within 2 hrs. The ovaries were washed in warm physiological saline several times at $37^{\circ} \mathrm{C}$ until obtaining clear saline and were placed in water bath at $37^{\circ} \mathrm{C}$ during collection of oocyte [7]. Before oocytes recovery, drying of the ovaries with sterile towel paper was necessary. Aspiration of oocytes from follicles $(2-8 \mathrm{~mm})$ was carried out using 18 gauge needle attached to a $10 \mathrm{~mL}$ plastic syringe containing few Millis of warmed aspiration medium (Tissue Culture Medium 199 (TCM-199) [8]. The examination and classification of recovered oocytes occurred according to their quality on the basis of compaction of cumulus corona investment and the homogeneity of ooplasm into: grade 1 (good) (had a homogenous evenly granular ooplasm and were surrounded by compact and dense cumulus cell layers ( $>3$ cumulus layers), 2 (fair) (had a homogenous ooplasm and were surrounded by 1-3 layers of cumulus cells), 3 (poor) (had uneven ooplasm (degenerated) and were completely devoid of cumulus cells around them) [9].

\section{In vitro maturation of oocytes}

Selected oocytes of good quality were washed three times in warmed aspiration medium and finally washed in in vitro maturation (IVM) medium (before their transfer to IVM medium (Tissue Culture Medium 199 (TCM-199). Oocytes were cultured in groups (5-15 oocytes) in $50 \mu \mathrm{L}$ of
IVM medium under paraffin oil in a $\mathrm{CO}_{2}$ incubator $\left(5 \% \quad \mathrm{CO}_{2}\right.$ and $90-95 \%$ relative humidity) at $38.5^{\circ} \mathrm{C}$ for $24 \mathrm{hrs}$ [8].

\section{In vitro fertilization}

Partial mechanical denudation of the cumulus cells surrounding the oocytes was applied by several pipetting of oocytes to facilitate penetration of the sperm cells to the oocytes. Oocytes were washed two times in warmed IVF medium (F-TALP). In vitro capacitation of buffalo spermatozoa was carried out by incubating motile spermatozoa separately by swim up technique. Microdroplet $(100 \mu \mathrm{L})$ of F-TALP medium containing BSA $(8 \mathrm{mg} / \mathrm{mL})$ and caffeine $(50 \mu \mathrm{g} / \mathrm{mL})$ with 2 million sperm $/ \mathrm{mL}$ was prepared to accommodate 10 oocytes. Co-incubation of sperm with oocyte was carried out in a humidified environment with $5 \% \quad \mathrm{CO}_{2}$ and $38^{\circ} \mathrm{C}$ temperature for $24 \mathrm{hrs}$ [10].

\section{In vitro culture of fertilized oocytes}

Fertilized oocytes were washed four times in culture medium before their transfer to the in vitro culture medium. Presumptive zygotes were transferred to the in vitro culture medium. In vitro embryo culture was applied inside incubator with $5 \% \mathrm{CO}_{2}$ at $38^{\circ} \mathrm{C}$ in humidified air.

\section{Experimental design}

Influence of monolayer on the quality and the developmental competence of in vitro produced buffalo embryos, Experiment 1(EXP1)

Fertilized oocytes were cultured either in Cell free media (CR1aa) and CR1aa supplemented with Granulosa cells monolayers (GCM) (prepared by washing of granulosa cells in CR1aa and culturing of these cells in the same medium for two days to obtain monolayer of granulosa cells) or Bovine oviductal cell monolayers (BOCM) (prepared by taking the oviductal cells from oviduct of buffalo and washing of them in CRlaa and culturing in the same medium for two days to obtain monolayer of oviductal cells.

Influence of lactoferrin on the quality and the developmental competence of in vitro produced buffalo embryos, Experiment 2 (EXP 2) 
Fertilized oocytes were cultured in CR1aa supplemented with lactoferrin at different concentrations of $10,20,50$ and $100 \mu \mathrm{g} / \mathrm{mL}$. Observation of the cleavage rate was done approximately $24 \mathrm{hrs}$ after the initiation of in vitro culture. Observation of the development of pre-implantation embryo is done up to 7 to 9 days of in vitro culture [8].

\section{Evaluation of in vitro produced embryos}

\section{Morphometric evaluation}

The evaluation of embryo quality was applied under a stereomicroscope according to morphological criteria of in vitro produced embryos. The most important criteria during the morphological evaluation of embryos include damage and fracture of the zona pellucida, shape, size, color and the number of damaged blastomeresrefernce and the presence of granules in the perivitelline space [6]. The first grade (very good): embryos are round and blastomeres have the same size, color and consistency. The second grade (good): embryos are slightly irregular, for example, as manifested by one swollen blastomere and an irregular shape of blastomeres. The third grade: more extensive irregularities are present. The fourth grade (poor): loose blastomeres, degenerated cells, damaged cell membranes, cells of various sizes, and color changes are noted.

Evaluation of cell number of embryos by nuclear Staining with Hoechst 33342

Embryos were removed from culture medium and were washed 2 times in $100 \mu \mathrm{L}$ of phosphate buffer saline containing $1 \mathrm{mg} / \mathrm{mL}$ polyvinyl pyrrolidone. The embryos were fixed in $100 \mu \mathrm{L}$ of paraformaldehyde solution for $1 \mathrm{~h}$ at room temperature. Embryos were washed in $100 \mu \mathrm{L}$ phosphate buffer saline / polyvinyl pyrrolidone for 3 times.

Embryos were stained with Hoechst 33342 dye (Sigma B2261) which was prepared following manufacturers' guidelines. Staining should be carried out with dimmed lights. Embryos were transferred to a $50 \mu \mathrm{L}$ of working solution. The cells were stained for 10 minutes. The embryos were washed two times by using $100 \mu \mathrm{L}$ of phosphate buffer saline polyvinyl pyrrolidone.
For mounting embryos to slides, clean slides were coated with poly-L-lysine through dipping into a 1:10 poly-L-lysine solution for few minutes. They were allowed to dry. Embryos were transferred to a slide coated with poly-L-lysine and were allowed to dry for $20 \mathrm{~min}$ at room temperature. Cover slip was placed over the slide and was allowed to dry for $2 \mathrm{hrs}$ in a dark place. The cells were counted under the fluorescent microscope with ultraviolet (UV) filter. Nuclei had blue color [11].

Evaluation by 3-(4.5-Dimethylthiazol-2-yl)2.5-diphenyltetrazolium bromide (MTT)

This test was carried out by incubating embryos with $0.25 \mathrm{mg} / \mathrm{mL}$ MTT in the culture media for $3 \mathrm{hrs}$ at $37^{\circ} \mathrm{C}$. The MTT enters the cells and passes into the mitochondria of living cells and reduced to an insoluble colored (purple) formazan product. The obtained formazan products were solubilized by overnight incubation in 50\% N,N-dimethyl formamide, $20 \%$ sodium dodecyl sulfate, $\mathrm{pH}$ 4.8 [12]. Quantitative measurement of the absorbance of this colored solution was performed at wave length $575 \mathrm{~nm}$ by ELISA reader.

\section{Statistical analysis}

Each experiment was replicated three times. Effect of replicates was non-significant. The data were expressed as means \pm SEM. The statistical significant difference was analyzed by one way ANOVA using costat computer program (1986). Values with different letters across treatments differed significantly. Differences of $\mathrm{P}<0.05$ were considered as statistically significant.

\section{Results}

Effect of cellular co culture on the development and quality of in vitro produced buffalo embryos

Data presented in Table 1 revealed that addition of oviductal cell monolayer to culture media significantly increased $(\mathrm{P}<0.05)$ the morula and the blastocyst development (24.65 \pm 2.68 and $15.12 \pm 3.36)$, compared with cell free media $(11.44 \pm 3.18$ and $3.55 \pm 1.80)$ and media with granulosa cell monolayer $(18.49 \pm 3.89$ and $11.86 \pm 3.42)$ respectively. Moreover, addition of oviductal cell and 
granulosa cell monolayer to culture media significantly increased $(\mathrm{P}<0.05)$ the cell number $(76.00 \pm 3.43$ and $73.00 \pm 4.43)$ and the mitochondrial function $(0.587 \pm 0.039$ and $0.452 \pm 0.058$ ) compared with cell free media $(47.00 \pm 3.19$ and $0.208 \pm 0.039)$, respectively. Data presented in Table 2 revealed that addition of oviductal cell mono-layer on culture media significantly $(\mathrm{P}<0.05)$ increased the proportion of good quality embryos (grade 1) $(66.67 \%)$ and decreased the proportion of poor quality embryo grade 4 (8.33\%) compared with cell free media $(25 \%)$ grade 1 embryos and $(37.5 \%)$ poor quality embryos (grade 4) (Figure 1).

Table 1: Effect of cellular co culture on the development and quality of in vitro produced buffalo embryos

\begin{tabular}{lcccccc}
\hline Treatment & No. of oocytes & Cleavage rate & Morula & Blastocyst & Cell number & $\begin{array}{c}\text { Mitochondrial } \\
\text { function }\end{array}$ \\
\hline Cell free & 53 & 19 & 6 & 2 & & \\
& & $36.27 \pm 11.47$ & $11.44 \pm 3.18^{\mathrm{b}}$ & $3.55 \pm 1.80^{\mathrm{b}}$ & $47.00 \pm 3.19^{\mathrm{b}}$ & $0.21 \pm 0.039^{\mathrm{b}}$ \\
Cumulus cell & 59 & 29 & 11 & 7 & & \\
& & $48.41 \pm 9.29$ & $18.49 \pm 3.89^{\mathrm{ab}}$ & $11.86 \pm 3.42^{\mathrm{ab}}$ & $73.00 \pm 4.43^{\mathrm{a}}$ & $0.45 \pm 0.058^{\mathrm{a}}$ \\
Oviductal cell & 61 & 36 & 15 & 9 & $76.00 \pm 3.43^{\mathrm{a}}$ & $0.59 \pm 0.039^{\mathrm{a}}$ \\
\hline
\end{tabular}

Table 2: Effect of cellular co culture on grading (quality) of buffalo embryos produced in vitro

\begin{tabular}{lccccc}
\hline Treatment & $\begin{array}{l}\text { No. of } \\
\text { Embryos }\end{array}$ & Grade 1 & Grade 2 & Grade 3 & Grade 4 \\
\hline Cell Free & 8 & $2(25)^{\mathrm{a}}$ & $2(25)$ & $1(12.5)$ & $3(37.5)^{\mathrm{a}}$ \\
Cumulus cell & 18 & $8(44.44)^{\mathrm{ab}}$ & $4(22.22)$ & $4(22.22)$ & $2(11.11)^{\mathrm{ab}}$ \\
Oviductal cell & 24 & $16(66.67)^{\mathrm{b}}$ & $2(8.33)$ & $4(16.66)$ & $2(8.33)^{\mathrm{b}}$ \\
\hline
\end{tabular}

Values with different superscripts in the same column are significantly different at $(\mathrm{P}<0.05)$.

\section{Effect of lactoferrin additive on the development and quality of in vitro produced buffalo embryos}

Data presented in Table 3 demonstrated that addition of $50 \mu \mathrm{g} / \mathrm{mL}$ lactoferrin to culture media significantly $(\mathrm{P}<0.05)$ increased the cleavage, morula and blastocyst rates $(51.23 \pm 4.86, \quad 25.53 \pm 4.39$ and $19.24 \pm 1.25)$ compared with control (38.80 \pm 9.28 , $13.63 \pm 5.10$ and $7.84 \pm 1.92$ ), respectively. Addition of lactoferrin by concentration 20 and $50 \mu \mathrm{g} / \mathrm{mL}$ to culture media led to a significant $(\mathrm{P}<0.05)$ increase in cell number $(62.6 \pm 4.33$ and $72.6 \pm 3.27)$ compared with control $(42.2 \pm 3.13)$ and 10 and $100 \mu \mathrm{g} / \mathrm{mL}$ lactoferrin (50.2 \pm 4.06 and $35.4 \pm 318)$. Also, it increased mitochondrial function $(0.382 \pm 0.054$ and $0.559 \pm 0.043)$ compared with control $(0.145 \pm 0.019)$ and concentration 10 and 100 $\mu \mathrm{g} / \mathrm{mL} \quad(0.260 \pm 0.035$ and $0.167 \pm 0.046)$, respectively.

Data presented in Table 4 and Figure 1 show that addition of lactoferrin by concentration $50 \mu \mathrm{g} / \mathrm{mL}$ on culture media led to a significant $(\mathrm{P}<0.05)$ increase in proportion of good quality embryos (grade 1) (78.57) and decrease in proportion of poor quality embryos (3.57) compared with control 41.67 (grade 1) and 25 (poor quality). While there were no significance differences in good quality and poor quality embryos among other concentrations and control. 
Table 3: Effect of lactoferrin additive on the development and quality of in vitro produced buffalo embryos

\begin{tabular}{|c|c|c|c|c|c|c|}
\hline $\begin{array}{l}\text { Concentration } \\
\text { of lactoferrin }\end{array}$ & $\begin{array}{c}\text { No. of } \\
\text { oocytes }\end{array}$ & Cleavage rate & Morula & Blastocyste & $\begin{array}{c}\text { Cell } \\
\text { number }\end{array}$ & $\begin{array}{l}\text { Mitochondrial } \\
\text { function }\end{array}$ \\
\hline Control & 68 & $\begin{array}{c}26 \\
38.80 \pm 9.28^{\mathrm{ab}}\end{array}$ & $\begin{array}{c}9 \\
13.63 \pm 5.10^{b}\end{array}$ & $\begin{array}{c}3 \\
7.84 \pm 1.92^{\mathrm{bc}}\end{array}$ & $42.2 \pm 3.13^{\mathrm{bc}}$ & $0.15 \pm 0.019^{c}$ \\
\hline $10 \mu \mathrm{g} / \mathrm{ml}$ & 57 & $\begin{array}{c}23 \\
39.22 \pm 6.76^{\mathrm{ab}}\end{array}$ & $\begin{array}{c}8 \\
14.22 \pm 2.24^{b}\end{array}$ & $\begin{array}{c}6 \\
10.29 \pm 2.64^{b c}\end{array}$ & $50.2 \pm 4.06^{\mathrm{b}}$ & $0.26 \pm 0.035^{\mathrm{bc}}$ \\
\hline $20 \mu \mathrm{g} / \mathrm{ml}$ & 63 & $\begin{array}{c}30 \\
47.74 \pm 2.58^{\mathrm{ab}}\end{array}$ & $\begin{array}{c}12 \\
18.99 \pm 2.45^{\mathrm{ab}}\end{array}$ & $\begin{array}{c}9 \\
14.20 \pm 2.53^{\mathrm{b}}\end{array}$ & $62.6 \pm 4.33^{\mathrm{a}}$ & $0.38 \pm 0.054^{\mathrm{b}}$ \\
\hline $50 \mu \mathrm{g} / \mathrm{ml}$ & 64 & $\begin{array}{c}33 \\
51.23 \pm 4.86^{\mathrm{a}}\end{array}$ & $\begin{array}{c}16 \\
25.53 \pm 4.39^{\mathrm{a}}\end{array}$ & $\begin{array}{c}12 \\
19.24 \pm 1.25^{\mathrm{a}}\end{array}$ & $72.6 \pm 3.27^{\mathrm{a}}$ & $0.56 \pm 0.043^{\mathrm{a}}$ \\
\hline $100 \mu \mathrm{g} / \mathrm{ml}$ & 57 & $\begin{array}{c}17 \\
29.47 \pm 2.24^{b}\end{array}$ & $\begin{array}{c}5 \\
8.62 \pm 1.25^{\mathrm{b}}\end{array}$ & $\begin{array}{c}3 \\
6.86 \pm 1.14^{\mathrm{c}}\end{array}$ & $35.4 \pm 318^{c}$ & $0.17 \pm 0.046^{\mathrm{c}}$ \\
\hline
\end{tabular}

Values with different superscripts in the same column are significantly different at $(\mathrm{P}<0.05)$.

Table 4: Effect of lactoferrin additive on grading (quality) of buffalo embryos produced in vitro

\begin{tabular}{|c|c|c|c|c|c|}
\hline \multirow{2}{*}{ lactoferrin } & \multirow{2}{*}{$\begin{array}{c}\text { No. of } \\
\text { embryos }\end{array}$} & \multicolumn{4}{|c|}{ Embryo grading } \\
\hline & & Grade 1 & Grade 2 & Grade 3 & Grade 4 \\
\hline Control & 12 & $5(41.67)^{b}$ & $2(16.67)$ & $2(16.67)$ & $3(25.00)^{b}$ \\
\hline $10 \mu \mathrm{g} / \mathrm{ml}$ & 14 & $8(57.14)^{\mathrm{ab}}$ & $2(14.29)$ & $2(14.29)$ & $2(14.29)^{\mathrm{ab}}$ \\
\hline $20 \mu \mathrm{g} / \mathrm{ml}$ & 21 & $13(61.90)^{\mathrm{ab}}$ & $4(19.05)$ & $2(9.52)$ & $2(9.52)^{\mathrm{ab}}$ \\
\hline $50 \mu \mathrm{g} / \mathrm{ml}$ & 28 & $22(78.57)^{\mathrm{a}}$ & $3(10.71)$ & $2(7.14)$ & $1(3.57)^{\mathrm{a}}$ \\
\hline $100 \mu \mathrm{g} / \mathrm{ml}$ & 8 & $3(37.5)^{b}$ & $1(12.5)$ & $1(12.5)$ & $3(37.5)^{b}$ \\
\hline
\end{tabular}

Values with different superscripts in the same column are significantly different at $(\mathrm{P}<0.05)$.

\section{Discussion}

This study revealed that addition of oviductal cell monolayer to culture media increased the morula and the blastocyst quality and development compared with cell free media and media with granulosa cell monolayer. These findings agreed with Kim et al. results [13] who indicated that co-culture with BOCM had a positive effect on in vitro produced bovine embryos development. Embryo co-culture systems have many advantages attempting to be similar to the in vivo conditions. The positive effect of monolayers is due to their secretion of some embryo trophic factors as growth factors and energy substrates to the culture medium (these factors improve the development of embryos) or due to removal of harmful substances as reactive oxygen species (ROS), ammonia and phosphate from the culture medium [14].

These results were nearly in accordance with Jamil et al. [15], who stated that development of 8-cell stage embryos was improved when embryos were cultured in TCM199 with BOCM than in TCM-199 alone. Also, addition of granulose cells and cumulus cells to IVM medium led to an increase in maturation rate of buffalo oocytes when compared to BOCM. These beneficial effects resulted from providing nutritional molecules that are important for growing and development of embryos and by transmitting signals that regulate oocytes maturation [15]. 

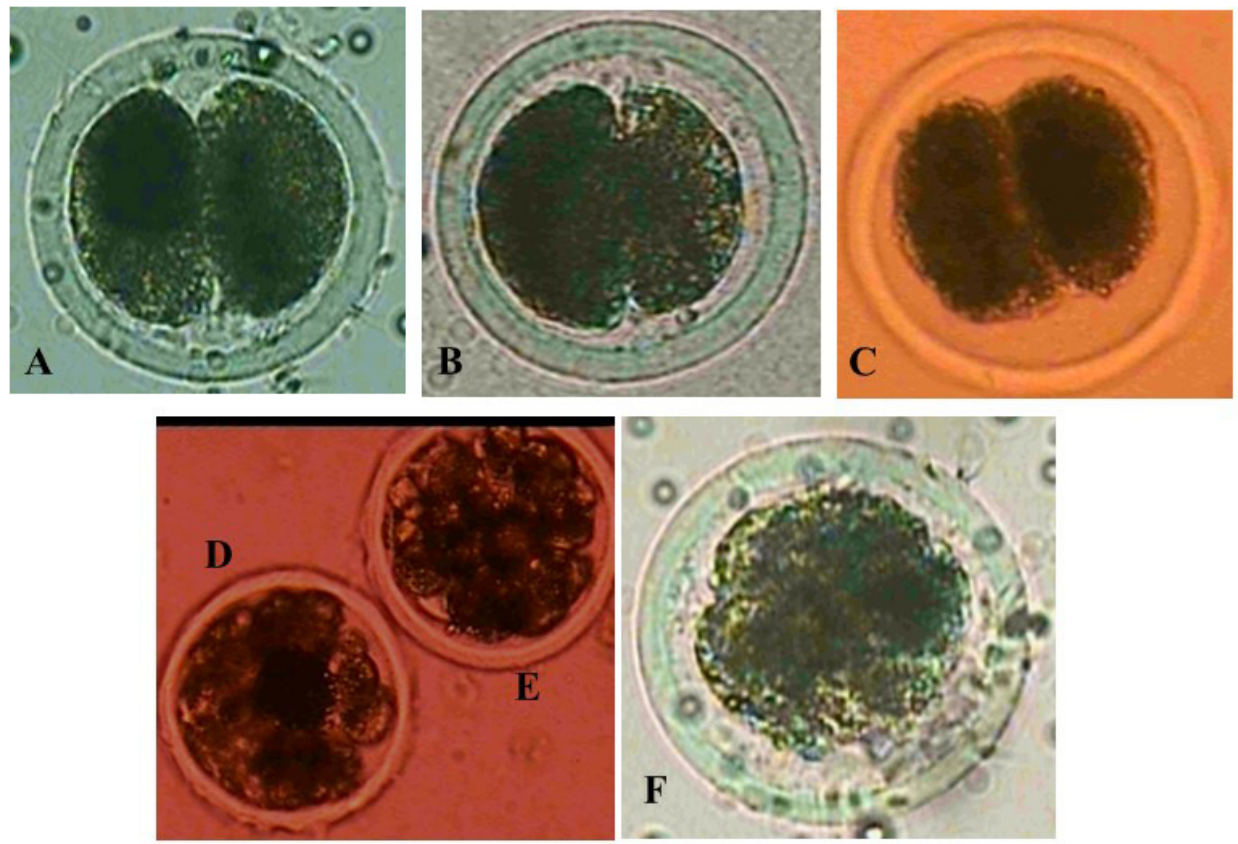

Figure 1: Two cell stage embryos (A: Grade 1, B: Fair quality, C: Poor quality), Compact Morula (D: Fair quality, E; F: Good quality).

The addition of oviductal cell and granulosa cell monolayers to culture media led to an increase in the number of cells. This result is in agreement with Ellington et al. [16] who noted that embryos co-cultured with BOCM and granulosa cell monolayers increased the embryo cell number. Addition of oviductal cell and granulosa cell monolayers during the culture step also significantly improved the mitochondrial function compared with cell free media. This may be due to the production of some growth factors such as platelet derived growth factor, activin, insulin like growth factor and fibroblast growth factor and energy substrates by cell monolayers (these secretions increase the metabolic activity and subsequently increase the cell number and the mitochondrial function) [17].

Addition of oviductal cell monolayer during culture step led to an increase in the number of good quality embryos (grade 1) and decrease in the number of poor quality embryo grade 4 compared with cell free media. This effect may be due to that BOCM protected the embryos by decreasing or removing the harmful substances from the culture medium or modifying the concentration of the medium components to a level more appropriate for embryo growth [18] and those produce specific embryo trophic factors which improve the in vitro development of embryos. The presence of BOCM at early stages (1-4 days) of embryo development enhanced the development and quality of embryo because this period mimics the in vivo conditions where the embryo is still in the oviduct [19].

The present study demonstrated that addition of lactoferrin (LF) by $50 \mu \mathrm{g} / \mathrm{mL}$ concentration to culture media increased the cleavage, the morula and the blastocyst rates compared with control. Moreover, a significant increase in the proportion of good quality embryos (grade 1) and decrease in the proportion of poor quality embryos compared with control was observed. Although the addition of lactoferrin to culture medium improved the developmental competence and the quality of in vitro produced buffalo embryos, the present study was the first study that recorded this effect. This effect of LF may result from that it maintains iron levels in the cell [5]. LF also has a higher resistance to proteolysis. 
LF has enzymatic activities in some reactions [20]. The mechanism by which LF acts as enzyme is unknown. The various activities of LF could be due to variations in the nature of the protein, multiple isoforms and degrees of glycosylation. LF's enzymatic activities can give explanation about many of its physiological function. These effects of lactoferrin may be the cause of improvement of buffalo embryos development when LF was added to the culture medium [21].

The present study revealed for the first time that addition of lactoferrin by concentrations 20 and $50 \mu \mathrm{g} / \mathrm{mL}$ to culture media resulted in an increase in the number of cells compared with control and concentrations 10 and 100 $\mu \mathrm{g} / \mathrm{mL}$ and significant increase in mitochondrial function compared with control. This increase in cell number and mitochondrial function may be attributed to antioxidant (decrease oxidative stress and apoptosis of the cells), antimicrobial and enzymatic activities of LF [20].

\section{Conclusion}

It could be concluded that, addition of oviductal cells (monlayer) or lacferrin to culture media can improve the quality and development of in vitro produced buffalo embryos.

\section{Conflict of interest}

The authors declare they have no conflict of interest.

\section{References}

[1] Madan, M.L.; Chauhan, M.S.; Manik, R.S. and Singla, S.K. (1994a): Pregnancies established from water buffalo (bubalus bubalis) blastocysts derived from in vitro matured, in vitro fertilized oocytes and co-cultured with cumulus and oviductal cells. Theriogenology, 42(4):591-600.

[2] Viana, J.H.M.; Luiz Siqueira, G.B.; Palhão, M.P. and Camargo, L.S.A. (2010): Use of in vitro Fertilization Technique in the Last Decade and its Effect on Brazilian Embryo Industry and Animal Production. Acta Sci Vet, 38(S 2): 661- 674.

[3] Abe, H.; Yamashita, S.; Satoh, T. and Hoshi, H. (2002): Accumulation of cytoplasmic lipid droplets in bovine embryos and cryotolerance of embryos developed in different culture systems using serum-free or serum-containing media. Mol Reprod Dev, 61(1):57-66.

[4] Rizos, D.; Ward F.; Duffy, P.; Boland, M.P. and Lonergan, P. (2002): Consequences of bovine oocyte maturation, fertilization or early embryo development in vitro versus in vivo: implications for blastocyst yield and blastocyst quality. Mol Reprod Dev, 61(2):234-48.

[5] González-Chávez, S.A.; Arévalo-Gallegos, S. and Rascón-Cruz, Q. (2009): Lactoferrin structure, function and applications. Int $\mathbf{J}$ Antimicrob Agents 33(4): 301.e1-301.e8.

[6] Bukowska, D.; Kempist, B.; Piotrowska, H.; Walczak, R.; Sniadek, P.; Dziuban, J.; Brussow, K.P.; Jaskowsk, J.M. and Nowic, M. (2012): The invasive and new non-invasive methods of mammalian oocyte and embryo quality assessment: a review. Vet Med, 57(4):169-176.

[7] Chauhan, M.S.; Manik, R.S.; Singla, S.K.; Katiyar, P. and Madan, M.L. (1997): Effect of insulin on in vitro development of in vitro produced embryos in co cultured system. Ind $\mathbf{J}$ Anim Prod Manag, 13:19-24.

[8] Kadoom, A.K.; Abdel-Khalek, A.E.; Shamiah, S.M; El-Sharawy, M.E. and Abdel-Razek, I.M. (2014): In vitro maturation, fertilization and development of pre pubertal and mature buffalo oocytes. Egyptian J Anim Prod, 51(2):65-69.

[9] Leibfried, L. and First, N.L. (1979): Characterization of bovine follicular oocytes and their ability to mature in vitro. J Anim Sci, 48(1):76-86.

[10] Parrish, J.J.; Susko- Parrish, J.L.; Leibfried -Rutledge, M.L.; Crister, E.S.; Eyestone, W.H. and First, N.L. (1986): Bovine in vitro fertilization with frozen thawed semen. Theriogenology, 25(4):591-600.

[11] Critser, E.S. and First, N.L. (1986): Use of a fluorescent stain for visualization of 
nuclear material in living oocytes and early embryos. Stain Technol, 61(1):1-5.

[12] Green, P.S. and Leeuwenburgh, C. (2002): Mitochondrial dysfunction is an early indicator of doxorubicin-induced apoptosis. Biochimicaet Biophysica Acta (BBA)- Molecular Basis of Disease, 1588(1): 94-101.

[13] Kim, C.L.; Ellington, J.E. and Foote, R.H. (1990): Maturation, fertilization and development of bovine oocytes in vitro using TCM-199 and a simple defined medium with co-culture. Theriogenology, 33(2): 433-440.

[14] Durnford, R.; Stubbings, R.B. and Ainsworth, L. (1994): Evaluation of culture systems containing bovine oviduct epithelial cells or granulosa cells to mature and maintain the developmental competence of bovine oocytes in vitro. Theriogenology, 42(2): 261-272.

[15] Jamil, H.; Samad, H.A.; Rehman, N.; Qureshi, Z.I. and Lodhi, L.A. (2010): Effect of Somatic Cell Types and Culture Medium on in vitro Maturation, Fertilization and Early Development Capability of Buffalo Oocytes. Pak Vet J, 31(2): 105-108.

[16] Ellington, J.E.; Carney, E.W.; Farrell, P.B.; Simkin, M.E. and Foote, R.H. (1990): Bovine 1-2-cell embryo development using a simple medium in three oviduct epithelial cell co-culture systems. Biol Reprod, 43(1): 97-104.

[17] Watson, A.J.; Hogan, A.; Hahnel, A.; Wiemer, K.E. and Schultz, G.A. (1992): Expression of growth factor ligand and receptor genes in the preimplantation bovine embryo. Mol Reprod Dev, 31(2):87-95.

[18] Gandolfi, F. (1994): Autocrine, paracrine and environmental factors influencing embryonic development from zygote to blastocyst. Theriogenology, 41(1): 95100.

[19] Cordova, A.; Perreau, C.; Uzbekova, S.; Ponsart, C.; Locatelli, Y. and Mermillod, P. (2014): Development rate and gene expression of IVP bovine embryos cocultured with bovine oviduct epithelial cells at early or late stage of preimplantation development. Theriogenology, 81(9): 1163-1173.

[20] Kanyshkova, T.G.; Babina, S.E.; Semenov, D.V.; Isaeva, N.; Valssov, A.V. and Neustroev, K.N. (2003): Multiple enzymatic activities of human milk lactoferrin. Eur $\mathrm{J}$ Biochem, 270(16):3353-61.

[21] Furmanski, P.; Li, Z.P.; Fortuna, M.B.; Swamy, C.V. and Das, M.R. (1989): Multiple molecular forms of human lactoferrin. J Exp Med, 170(2):415-29. 


\section{الملخص العربي \\ تأثير الظروف المختلفة للزرع المعملي علي نمو وجودة أجنة الجاموس المعبي}

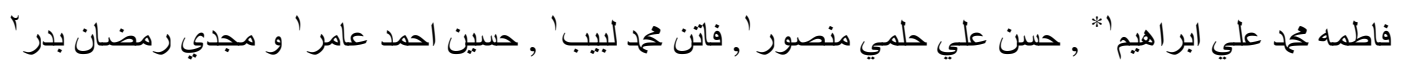

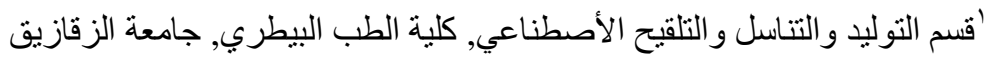

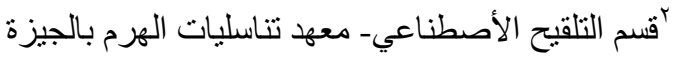

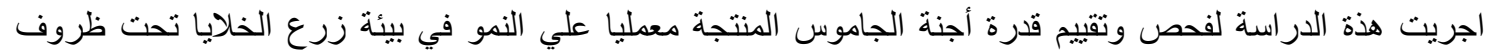

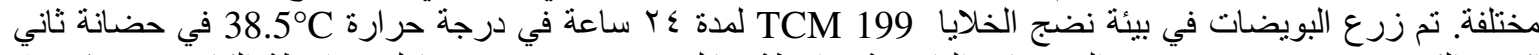

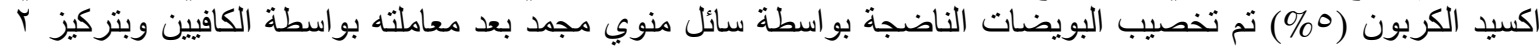

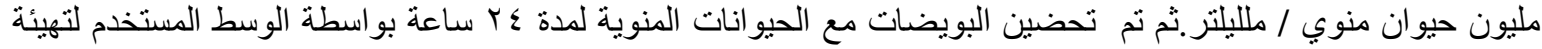

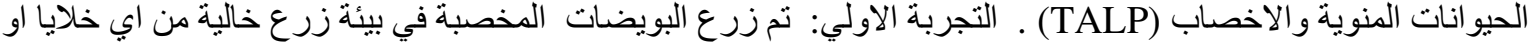

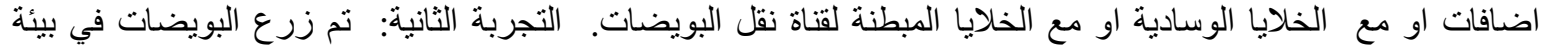

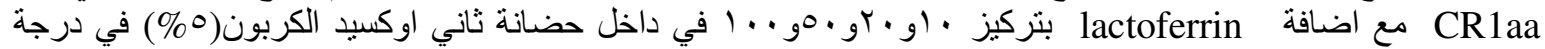
حرارة 38C

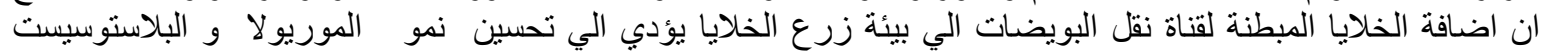

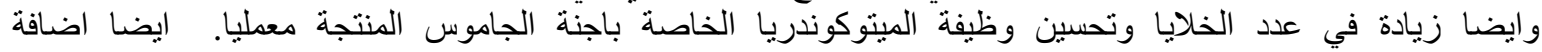

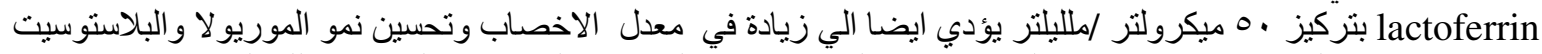

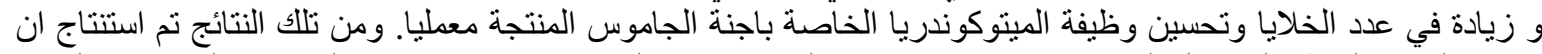
اضافة الخلايا المبطنة لقناة نقل البويضات واو lactoferrin الي بيئة زرع الخلايا يحسن جودة اجنة الجاموس المنتجة معطليا. 